\title{
A Novel Approach Towards Outcome Based Engineering Education for Continuous Quality Improvement: A Case study
}

\author{
A.R.Jakhale ${ }^{1}$ A. C. Attar $^{2}$ \\ ${ }^{1}$ Information Technology Department \\ ${ }^{2}$ Civil Engineering Department \\ ${ }^{1,2}$ RIT Sakharale, Maharashtra \\ 1jakhale.archana@gmail.com, ${ }^{2}$ abdulrashid.attar@ritindia.edu
}

\begin{abstract}
The Changes in the curriculum of engineering education have been an on-going need to be addressed and practiced by the universities to consistently generate well groomed learners suitable for industry. The Outcome Based Education (OBE) is an education system that emphasis on outcomes measurement rather than inputs of curriculum covered. Outcomes may include a range of knowledge, skills and attitudes. The objective of this study is to present a novel approach for the outcomebased assessment of engineering education for Information Technology (IT) department. A case study of an RIT engineering educational organization has been discussed to present novel approach. IT department of the case organization was exposed to the OBE and evaluated for Program-Outcomes (PO) entirely for all courses. In the studied organization the course evaluation was based on In Semester Evaluation (ISE), Mid Semester Evaluation (MSE), End Semester Evaluation (ESE). Mapping of Course Learning Outcome (CLO)-PO was done for the assessment. The feedback from alumnae, employers and students was taken to review course structure and CLO-PO with the highest academic achievements and better understanding of the course based on the OBE. This study shows that, in the studied organization there is positive impact of $\mathrm{OBE}$ on engineering education.
\end{abstract}

\section{A.R.Jakhale}

Information Technology Department

RIT Sakharale, Maharashtra

jakhale.archana@gmail.com
Keywords - Outcome Based Eeducation (OBE), Programme Educatinal Objective, Program Outcome (PO), Course Learning Outcome, Engineering Education.

\section{Introduction}

OBE approach has been adopted by a number of countries such as USA and Australia for many years. OBE can be stated as " a comprehensive approach to organizing and operating an education system that is focused in and defined by the successful demonstrations of learning sought from each student" [1]. In a nutshell, OBE is an education approach to education in which decisions about the curriculum are driven by the exit learning outcomes that the students should display at the end of the programme. OBE can be summed up as results-oriented thinking and is the opposite of input-based education where the emphasis is on the educational process. In this way, the desired outcomes are determined first and the programme curriculum, teaching and learning methodology and supporting facilities are then designed to achieve the intended outcomes. During the course of the programme, various measurement methods are used to gauge the level of the outcomes that have been attained by the students. Various counter measures are then applied in order to further improve the attainment of the outcomes. This forms the basis of Continuous Quality Improvement (CQI) in applying OBE.

The changes made in the curriculum are to reflect the needs of the stakeholders (students, alumni and 
employers) and industry demands for competent engineers. Accreditation Board for Engineering and Technology (ABET) has encouraged and monitored development of IT programme both to develop a skill and assess individual students and to provide evidence for assessing standards in programs of study[2].

This paper has introduced a case study for implementation of $\mathrm{OBE}$ for continuous quality improvement with evaluation of assessment tools for undergraduate Information Technology programme in RIT engineering education organization.

\section{Framework For Obe}

OBE is an education system designed based on predefined objectives and learning outcomes. It has encouraged and monitored development of different courses both to develop a skill and assess individual students and to provide evidence for assessing standards in programs of study. However the initial challenge is to classify the skills and to link the components of the OBE setup to formulate the various assessment strategies. OBE focuses on learning by:

a. Defining programme educational objectives(PEO) The PEO are the skills that the graduate should have after four years completing the a programme .

b. Define programme outcomes (PO). PO are desirable graduate attributes at the time of graduation.

c. Define course learning objectives (CLO) [3], i.e. at the end of the course the student should be able satisfy these objectives and they are mapped with the program outcomes (PO). This mapping is known as CLO-PO matrix[4].

d. Assessment for the achievement of programme educational objectives.

PEOs are the broad statements that describe the career and professional accomplishments that the program is preparing the graduates to achieve. The PEOs are established in consultation with the stake holders of the department like students, faculty, parents, alumni, industry, management etc. The job profile of IT engineer is also considered.

PEO_1: Graduate shall demonstrate knowledge of Information Technology theory and practices to analyze, formulate, solve social and engineering problems.
PEO_2: Graduate shall pursue successful career in IT industries as a software engineer, database administrator, network administrator, IT Manager and system analyst.

PEO_3: Graduate shall exhibit professional skills comprising ethical attitude, effective communication, leadership and teamwork.

The following process is implemented while establishing the PEOs (see Fig. 1):

1. The vision and mission of the department is taken as basis to interact with various stakeholders of the department.

2. Feedback from employers is taken which describes what the expectations from the graduates are.

3. Entry survey of the newly admitted students is taken which describes why the student has taken admission to the program and what is his career aim.

4. Feedbacks from parents and alumni are also taken into consideration.

5. Brain storming sessions are held in presence of all faculty members and Board of Studies.

6. The department advisory board formulates the accepted views based on which PEOs are established.

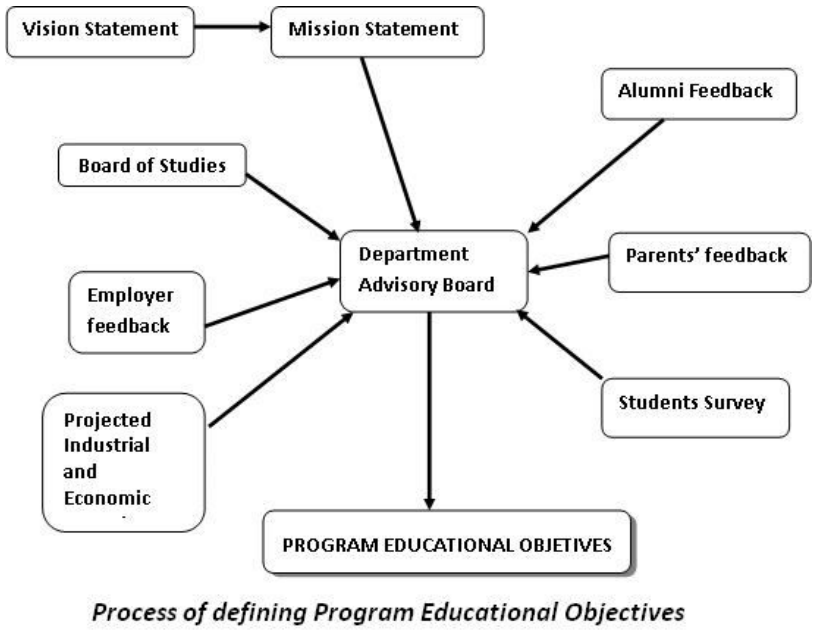

Fig 1 Process of defining PEO

All Students in the program are expected to acquire these outcomes at the end of their four year of studies through various courses offered in the bachelor degree in Information Technology.

Program outcomes are established through the consultation process with stake holders keeping the 
graduate attributes defined by NBA as basis. Department vision, mission and program educational objectives are also kept in view. The professional society namely ASME guidelines on curriculum and graduate outcomes are also considered. The following steps are employed for defining the POs:

1. The program outcomes are drafted in presence of all faculty members and board of studies.

2. Consultation is done with all the key stake holders of the program with respect to what the students are expected to know and be able to do after graduation.

3. The views collected are summarized by the faculty members, head of the department and board of studies keeping in view the department vision, mission and PEOs. The graduate attributes prescribed by NBA are also taken into consideration.

4. Once the views are accepted by the department advisory board, then the program outcomes are defined and endorsed by the advisory board.

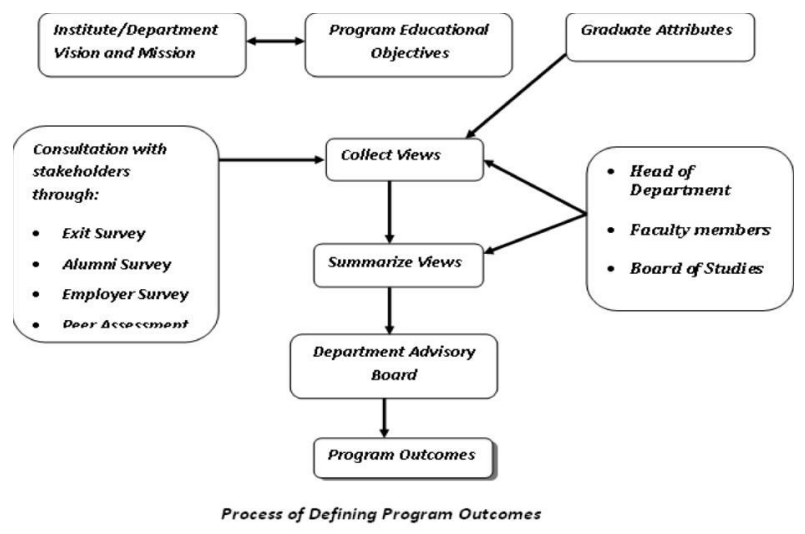

Fig 2.Process of Defining Program Outcomes

The PO for Information Technology programme is outlined in Table 1. The list of PO emphasizes the expectations for students of bachelor of Information Technology upon their graduation.

Table 1 Program Outcomes For Information Technology

\begin{tabular}{|ll|}
\hline POs & Abet a-k \\
\hline PO1 & a. Demonstrate knowledge of mathematics, science \& engineering \\
\hline PO2 & $\begin{array}{l}\text { b. Identify, analyze, and formulate problems using Information } \\
\text { Technology }\end{array}$ \\
\hline PO3 & $\begin{array}{l}\text { c. Analyze and interpret data for modeling, designing and } \\
\text { developing software. }\end{array}$ \\
\hline PO4 & $\begin{array}{l}\text { d. Design and develop software systems of varying complexity to } \\
\text { meet the desired needs }\end{array}$ \\
\hline
\end{tabular}

\begin{tabular}{|ll|}
\hline PO5 & $\begin{array}{l}\text { e. Use modern tools to evaluate and implement computer } \\
\text { systems }\end{array}$ \\
\hline PO6 & $\begin{array}{l}\text { f. Communicate information efficiently, reliably \& securely using } \\
\text { computer networks }\end{array}$ \\
\hline PO7 & $\begin{array}{l}\text { g. Succeed in competitive examinations like GATE, GRE and } \\
\text { various professional certifications in Information Technology }\end{array}$ \\
\hline PO8 & h. Exhibit professional skills and ethical responsibilities \\
\hline PO9 & i. Communicate effectively in both verbal \& written form \\
\hline PO10 & j. Work effectively in teams and have enduring learning skills. \\
\hline PO11 & $\begin{array}{l}\text { k. Analyze the impact of engineering solutions on individuals, } \\
\text { society and environment }\end{array}$ \\
\hline PO12 & $\begin{array}{l}\text { l. Apply the knowledge of engineering and management principles } \\
\text { and to one 's own work, as a member and leader in a team, to } \\
\text { manage projects and in multidisciplinary environments. }\end{array}$ \\
\hline
\end{tabular}

Each course has defined course learning outcomes that are mapped to the program outcomes and a set of performance criteria that are used to provide quantitative measurement of how well course outcomes are achieved. For example the course outcome for java programming course is outlined below(Table 2).

Table 2 Course Learning Objectives For Java Programming Course

\begin{tabular}{|ll|}
\hline CLOS \\
\hline CL1 & $\begin{array}{l}\text { Understand the concept of OOP and the principles of inheritance, } \\
\text { polymorphism, encapsulation and method overloading. }\end{array}$ \\
\hline CL02 & $\begin{array}{l}\text { Implement programs using string functions, exception handling } \\
\text { concepts and java standard class library. }\end{array}$ \\
\hline CL03 & Implement JAVA applets, package and use IDE 's to develop \\
& JAVA applications. \\
\hline CL04 & $\begin{array}{l}\text { Develop GUI based applications by using AWT \& Swing } \\
\text { packages and implement database connectivity and network } \\
\text { programming in java. }\end{array}$ \\
\hline CL05 & $\begin{array}{l}\text { Analyze the difference between java and other programming } \\
\text { languages. }\end{array}$ \\
\hline
\end{tabular}

\section{Implementation}

Modes of delivery of courses help in attainment of the Pos The following are the various modes of content delivery of courses:

पLecture interspersed with discussion.

口Tutorials

口Demonstrations of modern tools

QQuiz

Industrial Visits. 
पAssignments/Group Assignments.

पPresentations

GGroup Discussions

पMini Projects/Projects.

$\mathrm{QE}$ learning recourses like NPTEL lectures, open course wares etc.

Assessment tools used to assess the impact of delivery of course/course content contribute towards the attainment of course outcomes/programme outcomes.The generalized mapping of the course delivery methods to the program outcomes is shown in Table 3 below. The program outcomes are achieved through curriculum that offers a number of mandatory courses as well as elective courses. Each course has defined course outcomes that are mapped to the program outcomes and a set of performance criteria that are used to provide quantitative measurement of how well course outcomes are achieved.

Table 3 Mapping For Course Delivery Method To Program Outcome

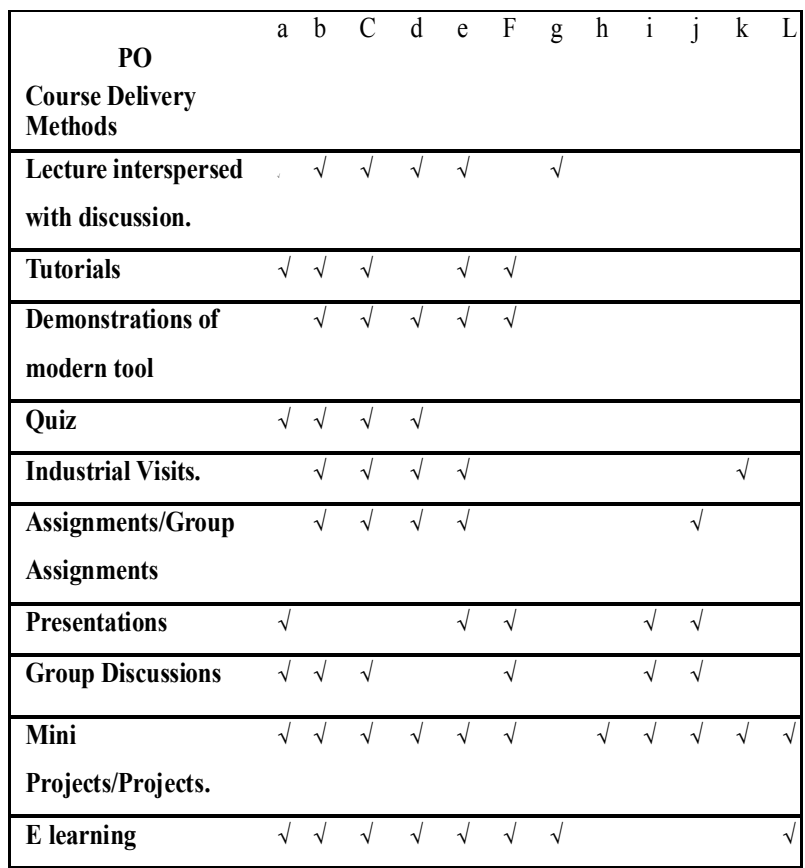

The linkage among program outcomes and course outcomes is shown in the table below. The course outcomes are thus directly and quantitatively assessed, and are tied to the program outcomes as shown in the course syllabi [5]. Therefore if the course outcomes are met, the program outcomes are met.

The course outcomes of each core course are mapped to the Program Outcomes with a level of emphasis being either strongly correlated (2) and moderately correlated (1) (TABLE 4). The level of emphasis of a program outcome is determined by the weight used for assessing the outcome in each course.

Table 4. Clo/po Mapping For Java Programming Course

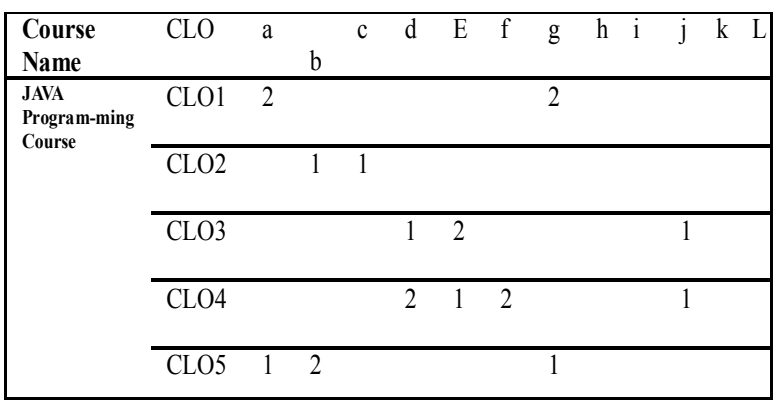

In JAVA programming course, it can be observed that $\mathrm{PO} 1, \mathrm{PO} 2, \mathrm{PO} 4, \mathrm{PO} 7$ are strongly and PO8, PO9 ,PO11, PO12 are weak achieved by students.

\section{Assessment Strategies}

To ensure the quality of the outcome based Information Technology, faculty need to provide assessment tools to measure outcomes of each undergraduate engineering course[6].

Frequency of assessment process is given below.

Tools of PO assessment: -

Direct assessment

1. Exams

2. Assignments

3. Projects

4. Tutorials

5. Lab work/Programming

6. ProjectExhibition

7. Presentations.

पA performance target is set for each outcome.

DIn semester Evaluation of the course, assignments and tutorials are planned and conducted.

$\square$ At the end of semester, evaluation data is analyzed to check attainment of PO's .

पQuality of the question papers is critically checked by departmental advisory board to ensure attainment 
of CLO's, PO's.

aSeminar and project content is monitored and upgraded continuously.

口Content of lab work, tutorials and assignments is designed to meet set PO's.

पHead of the department analyzes each outcome and defined set of measurable attributes for each outcome by taking consent of Department Advisory Board.Indirect Assessment

口Alumni survey

口Employer survey

口Course end survey

口Technical competitions

$\mathrm{F}$ eedback from Alumnae and Employers is taken by the department through Training \& Placement and Alumni cell The suggestions given are incorporated in curriculum during BOS meeting.

पAt the end of course feedback is taken from students about course content and discussed in BOS meeting. Outcomes are incorporated in curriculum.Frequency of assessment process.

Direct assessment

1. Exams (Twice a semester)

2. Assignments, tutorials and Practical's (Continuous assessment)

3. Projects (Quarterly)

4. Presentations ( Four presentations per year)

Indirect Assessment

1. Alumni and Employers feedback (Yearly)

2. End of course survey (HalfYearly)

\section{Result}

Summarization of the evaluation processes and analysis illustrating the extent to which each of the programme outcomes are attained.

Table 5. Ability Criteria With Score

\begin{tabular}{|ll|}
\hline Ability Criteria & Score \\
\hline 1- Unsatisfactory & 00 \\
\hline 2- Developing & 20 \\
\hline 3- Satisfactory & 30 \\
\hline 4- Exemplary & 50 \\
\hline
\end{tabular}

Table 6 .Assessment Matrix

\begin{tabular}{|c|c|c|}
\hline PO & Assessment Method & \\
\hline & Direct Assessment & Indirect Assessment \\
\hline PO1 & $\begin{array}{l}\text { ISE/MSE/ESE } \\
\text { Evaluation }(85 \%)\end{array}$ & Course End Survey (15\%), \\
\hline PO2 & $\begin{array}{l}\text { ISE/MSE/ESE } \\
\text { Evaluation }(85 \%)\end{array}$ & Course End Survey, $(15 \%)$ \\
\hline PO3 & $\begin{array}{l}\text { ISE/MSE/ESE } \\
\text { Evaluation }(85 \%)\end{array}$ & Course End Survey (15\%) \\
\hline PO4 & $\begin{array}{l}\text { ISE/MSE/ESE } \\
\text { Evaluation }(70 \%)\end{array}$ & $\begin{array}{l}\text { Course End Survey, Rubrics } \\
\text { (Seminar, Projects) }(30 \%)\end{array}$ \\
\hline PO5 & $\begin{array}{l}\text { ISE/MSE/ESE } \\
\text { Evaluation }(80 \%)\end{array}$ & Course End Survey, $(20 \%)$ \\
\hline PO6 & $\begin{array}{l}\text { ISE/MSE/ESE } \\
\text { Evaluation }(80 \%)\end{array}$ & $\begin{array}{l}\text { Course End Survey, Rubrics } \\
\text { (Seminar, Projects) }(20 \%)\end{array}$ \\
\hline PO7 & $\begin{array}{l}\text { Rubrics(Seminar, } \\
\text { Workshop,Co- } \\
\text { Curricular \& Extra }(30 \%)\end{array}$ & $\begin{array}{l}\text { Alumni Survey, Student } \\
\text { Feedback }(70 \%)\end{array}$ \\
\hline PO8 & $\begin{array}{l}\text { Rubrics(Seminar } \\
\text {,Workshop,Co- } \\
\text { Curricular \& Extra } \\
\text { Curricular, Oral } \\
\text { Examination }(30 \%)\end{array}$ & $\begin{array}{l}\text { Alumni Survey, Student } \\
\text { Feedback }(70 \%)\end{array}$ \\
\hline PO9 & $\begin{array}{l}\text { ISE/MSE/ESE } \\
\text { Evaluation }(70 \%)\end{array}$ & $\begin{array}{l}\text { Seminar, Training Program \& } \\
\text { Workshop }(30 \%)\end{array}$ \\
\hline PO10 & $\begin{array}{l}\text { ISE/MSE/ESE } \\
\text { Evaluation }(30 \%)\end{array}$ & $\begin{array}{l}\text { Seminar, Co-Curricular } \\
\text { Activities, Training Program } \\
(70 \%)\end{array}$ \\
\hline PO11 & $\begin{array}{l}\text { ISE/MSE/ESE } \\
\text { Evaluation }(50 \%)\end{array}$ & $\begin{array}{l}\text { Rubrics (Seminar, Co- } \\
\text { Curricular Activities, Training } \\
\text { Program) }(50 \%)\end{array}$ \\
\hline PO12 & $\begin{array}{l}\text { ISE/MSE/ESE } \\
\text { Evaluation }(50 \%)\end{array}$ & $\begin{array}{l}\text { Rubrics (,Co-Curricular } \\
\text { Activities, Extra Curricular } \\
\text { Activities , Projects } \\
\text {,workshop) }(50 \%)\end{array}$ \\
\hline
\end{tabular}

Out of all the above mentioned assessment tools for POs, the following tools are used for assessment of POs for the Information Technology programme. Since only one class is considered for assessment, the attainment of POs is partial.

1. Evaluation of ISE, MES and MSE answer papers

2. Course End Survey

3. Rubrics for $\mathrm{Co}$-Curricular Activities

4. Rubrics for Extra Curricular Activities

5. Rubrics for Training Programs/Workshops

6. Rubrics for Projects and Seminar

7. Alumni survey

8. Student Feedback

Practical/Oral Examination Survey from external Examiners. As seen from the above table, All PO's are assessed by both direct as well as indirect tools. Hence for PO1, $\mathrm{PO} 2$, PO3, PO4, PO5 PO6, Po9 having more wightage to direct tool and the PO7 ,PO8, PO10 
having more wightage indirect tool. Rest of all the POs are assessed through equally direct and indirect tools. Hence average of all those assessments is considered. The summary of the assessment of PO by direct and indirect methods is given in the Fig 3 . below

Performance evaluation is done by measuring the program outcomes mapping to CLO through different activities in Information Technology. The expected level of attainment for each of the program outcomes is calculated and summaries of the results of the evaluation processes and an analysis illustrating the extent to which each of the programme outcomes are attained; The percentage of attainment program outcome.

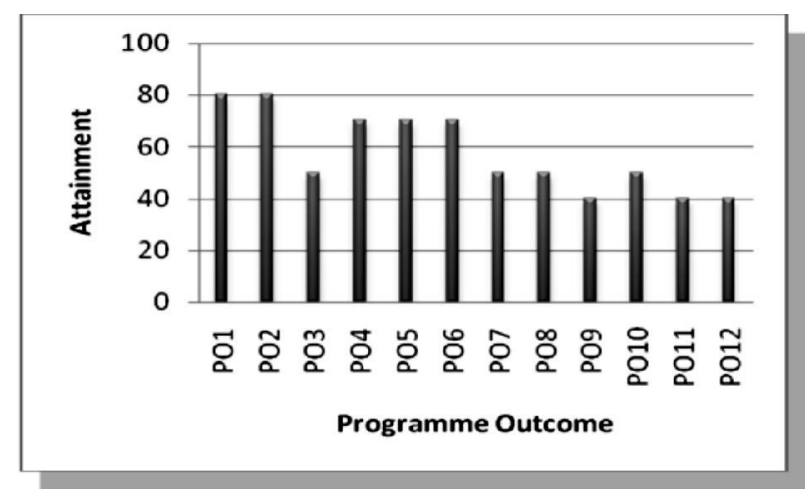

Fig 3.Attainment for Information Technology

Towards improvement of information Technology Programme, feedback from alumnae and employers is taken by the department through training \& placement and alumni cell. The suggestions given are incorporated in curriculum during BOS meeting. At the end of course feedback is taken from students about course content and discussed in BOS meeting. Outcomes are incorporated in curriculum . for example, i) A multidisciplinary approach which involves projects appropriately from multiple discipline to redefine problems outside of normal boundaries and reach solutions based on a new understanding of complex situations. ii) subject like professional skill development, open elective at B.Tech final year level. Thus, data give us confidence that the development of assessment tool for the outcome based engineering courses is working in the positive direction. OBE provide continuous quality improvement model for engineering education.

\section{Conclusion}

The OBE implementation of $\mathrm{CO}$ and $\mathrm{PO}$ attainment has been explored for IT programme in RIT engineering organization, that were offered to all undergraduates students. This novel approach has been implemented in all the programmes of RIT for continuous quality improvement of engineering education. The implementation of OBE in engineering education is a cyclic continuously improving model with the assessment of the outcomes. It is not the end but just the means to achieve the desired outcomes. Effective implementation of OBE gives opportunity for new ideas and challenges to develop an education model which resulted in improved learning outcomes. The data from RIT gives confidence that the development of assessment tool for the outcome based engineering courses is working in the positive direction.

\section{Acknowledgment}

The authors are grateful to Director of RIT Dr.Mrs. S.S.Kulkarni for their advice and continuous support .

\section{References}

[1] W.Spady , "Outcomes Based Education: Critical Issues and Answers ", American Association of School Administration: Arlington, Virginia, 1994

[2] D.Pdmashree, M. Vijayalakshmi and G.H. Joshi, "A novel approach to carrying out mini project in Computer Science \& Engineering", Engineering Education: Innovative Practices and Future Trends(AICERA), IEEE International Conference. 978-1-4673-2267-6, 2012.

[3] M. Vijayalakshmi, D. Padmashree, and G.H. Joshi, "An innovative approach to problem identification and design for capstone projects", Engineering Education: Innovative Practices and Future Trends (AICERA), 2012

[4] R. Hashim, M. Azizi , "Implementing Outcome Based Education Using Project Based Learning at University of Malaya", European Journal of Scientific Research ISSN 1450-216X, Vol.26 ,No.1 80-86, 2009

[5] A. Masni-Azian, , A.Rahimah, " Towards OBE: A Case Study of Course Outcome (CO) and Programme Outcome (PO) Attainment for Product Design and Development Course", IOSR Journal of Research \& Method in Education, Vol. 4, 2 ,5561,2014

[6]E. Valderrama, M. Rullán and F. Sánchez,"Guidelines For The Final Year Project Assessment In Engineering " 978-1-4244-47145/09 IEEE, San Antonio, TX 39th 